\title{
Traditionalism Through the Prism \\ of the Neosentimentalist Discourse \\ (Based on V. Gurkin's Dramaturgy)
}

\author{
Tatiana N. Breeva* \\ Kazan Federal University \\ 18 Kremlyovskaya Str., Kazan, 420008, Russia
}

Received 17.01.2016, received in revised form 28.02.2016, accepted 05.05.2016

The article analyzes the specificity of the traditionalism trends functioning in the Russian literature of the second half of the XX century in the context of neosentimentalism discourse. Its universality and functional multiplicity provides its widespread penetration into the literary process of that time and integration with various literary phenomena: postmodernism, feminine prose, literature of "new biographism", "new drama", etc. Neosentimentalist discourse activation becomes a means of overcoming crisis results of postmodern intellectual paradigm and primarily performs the rehabilitation function, reviving a set of constants, including an ethical one and that of human existence. Axiological potential of neosentimentalist discourse is represented through the category of corporeity, acquiring positive semantic connotations. Integration of neosentimentalist discourse with the literature of traditionalism provides the evidence of a state of its (literature) crisis and tendency to vary the forms and methods of artistic expression.

Keywords: literature of the Russian traditionalism, neosentimentalist discourse, postmodernist artistic paradigm, feminine prose, $V$. Gurkin's dramaturgy.

DOI: 10.17516/1997-1370-2016-9-5-1174-1180.

Research area: philology.

One of the main tendencies of the Russian literature of the last decades is the emergence of "new sentimentality" (in M. Epstein's terminology). The sentimentalist turn, which is differently defined in literary criticism (neosentimentalism, new sentimentality, sentimentalist discourse), is stated by almost all the researchers analyzing the modern state of the Russian prose. The whole group of authors such as L. Petrushevskaya, L. Ulitskaya, M. Palei, N. Gorlanova, G. Shcherbakova, S. Vasilenko,
T. Kibirov, E. Grishkovets, N. Kolyada, etc. work in the context of these definitions.

Most literary scholars regard the emergence of this tendency as a logical result of the " "postmodernist' era outcome", a response to the emergence of "a feeling of some new seriousness" (M. Epstein). Describing new sentimentality, N. Leiderman and M. Lipovetskii note that "in its pathos it is opposite to postmodernist skepticism and gets back to the traditions of the artistic system of a romantic type. $<\ldots>$ The "new

(C) Siberian Federal University. All rights reserved

* Corresponding author E-mail address: tbreeva @mail.ru 
sentimentalism" works actualize the memory of cultural archetypes filled with great significance". However, "these archetypes are not canonized; they have shifted from their semantic nests; and most importantly ... they are not in irreconcilable antagonism with the "filth" surrounding them" (Leiderman, Lipovetskii, 2001, 85).

An active character of sentimentalist discourse, its fundamental irreducibility to only one element of inter-textual poetics is due to its correlation with the problem of self-identification as one of the dominant vectors of a contemporary cultural space. According to I.V. Dubrovina, "blockage of the collective and personal identification mechanisms problematizes the identity reality for a human of the postmodern era in general" (Dubrovina, 2013, 112).

It is a well-known fact that mobility of identity is registered in almost all post-modern philosophy. Thus, G. Deleuze and F. Guattari note the absence of "permanent identity, $<$ a man T.B.> is always decentred when removed from the states he gets through" (Deleuze, Guattari, 2007, p. 41). According to Foucault, "the identity, which we attempt to support and unify under a mask, is in itself only a parody: it is plural; countless spirits dispute its possession; numerous systems intersect and compete... And history will not discover a forgotten identity, eager to be reborn, but a complex system of distinct and multiple elements, unable to be mastered by the powers of synthesis" (Foucault, 1996, 81).

Another justification of the process of selfidentity transformation at the present cultural stage is given by A.G. Dugin, considering the movement from modern to postmodern as a shift from logic to logistics and logeme: "Logeme in a sociological sense is fragmentation of the logistic rationality into a smaller, sub-individual level. For a logeme the object of ordering is an individual's body, psyche and objects they are very close with - clothes, food, fine emotions, experiences, feelings” (Dugin, http://konservatizm.org/ konservatizm/sociology/280610193723.xhtml). They result is a triumph of "nocturne metaphors", which are, first of all, food and sex industries euphemizing human existence.

In this context, neosentimentalism can be considered as a method of decoding of euphemized patterns of life, on the one hand, and a version of norms reconstruction that overcomes postmodern decentrism, on the other hand. That is why the range of attributing this phenomenon is extremely wide and even eclectic, ranging from nominations to the target object itself. N. Leiderman and M. Lipovetskii refer the female prose to "new sentimentalism", considering the latter to be a form of actualization of corporeity and archetypicality together, or, in other words, a process of returning to postmodern understanding of the body of the primary physiological sense and axiological fullness. Dwelling on sentimentalist discourse, C. Chuprinin notes the writers' attraction to it, the writers being focused on "new biographism", which is meant to be the same process of secondary axiologization. Giving a detailed analysis of the specifics of the sentimentalist discourse functioning in the Russian female prose in L. Ulitskaya's and L. Petrushevskaya's work, T.G. Prokhorova distinguishes two forms of its presentation: fiction and non-fiction. According to the researcher, the former is to a greater extent inherent to L. Ulitskaya's works. It manifests "itself in the sphere of the characters' outlook, the characters being treated with the author's noticeable irony". The latter is more inherent to L. Petrushevskaya's works whose "sentimental discourse plays the role of a supporting structure defining the strategy of cooperation between all links in the "author narrator - character - reader" communicative chain" (Prokhorova, 2012, p. 314).

Recognizing all the correctness of the former analysis, it is, however, possible to 
assume that the difference of the sentimentalist discourse functioning in L. Petrushevskaya's and L. Ulitskaya's prose is primarily due to a different degree of correlation with a literary phenomenon it refers to. The issue of the extent and nature of L. Petrushevskaya's and T. Tolstaya's work involvement in the female prose is still very controversial. So, G.A. Pushkar', giving the classification of the female prose, defines T. Tolstaya's creativity type as androgynous, and L. Petrushevskaya's one as annihilation, which is in contrast to femininity of L. Ulitskaya's creative work. N.V. Vorobyova is even more consistent in her conclusions. She states a special nature of feminine self-identity and self-positioning in L. Petrushevskaya's works, which, in its turn, determines the specifics of their artistic embodiment.

The focus of sentimentalist discourse on the process of designing a new concept of masculinity that forms a set of images of the representative Other is turning into a more typical variant of the female prose. That is why the discourse is represented mainly on the level of characters and images, that can be observed L. Ulitskaya's works, for example.

As for L. Petrushevskaya's artistic work, her approach is partly linked with the sentimentalist discourse version, which is characteristic of postmodernist artistic paradigms and complies with Einstein's definition of "anti-irony", illustrated on the example of V. Erofeev's and T. Kibirov's work. In this case the convergence of these two diverse names as L. Petrushevskaya and N. Kolyada is possible.

Registering the sentimentalist discourse penetration in the "new drama" of the turn of XX - XXI centuries, the researchers mention a fairly wide range of names, including the works by E. Grishkovets, N. Kolyada, I. Vyrypayev, etc. At the same time the case of N. Kolyada takes a special place in the context of the problem of the research. This is at least because of the fact that sentimentalist discourse is total in its drama, manifests itself in almost entire palette of texts and becomes a means of decoding a lower corporeity while performing the same function of anti-irony. Analyzing the specificity of the sentimentalist discourse representation in the playwright's works, I.V. Dubrovina speaks about the body as a "conductor of the "human complex", that is typologically close to the aesthetics of sentimentalism" (Dubrovina, 2013, 135). Comparing N. Kolyada's and E. Grishkovets's dramaturgy, the researcher rightly notes that whereas E. Grishkovets's poetics, "being a consistent remake of the defining properties of the sentimental aesthetics, is an external alternative to postmodernism, N. Kolyada's dramaturgy is a complex reconstruction-transformation of the sentimentalist code on the post-modernist platform" (Dubrovina, 2013, 135).

With regard to other artistic versions of "new drama", sentimentalist discourse starts working somewhat differently. Firstly, it is completely optional for works of this kind, and secondly, in the context of the performative aesthetics, offering an extremely wide palette of corporal practices implementation, sentimentalist discourse loses its function of the category of corporeity rehabilitation. From this point of view, it may become a bodily code antagonist, being a form of representation of ritualization of life. In this case sentimentalist discourse, which externally creates the effect of a ritual of life stereoscopicality, is a false version of self-identification, as a rule.

Such is the case for V. Levanov's play "Peeping Outs". While analyzing it, the researchers almost always note an open focus of the text on the tradition of an "anti-Christmas" story (like, for example, F.M. Dostoevsky's story "The Beggar Boy at Christ's Christmas Tree"). The only content of the play being a fading dialogue of two small children trapped in 
a very confined space and doomed to death, the sentimentalist discourse of the play is absolutely not supported by the characters themselves and most likely becomes one of the generations "of the horizon of readers' expectations". Principal non-projection of sentimentalist discourse on "children's" world determines its reference to the adult view. T.N. Volkova notes that quite an obvious reference of Levanov's text to F.M. Dostoevsky's story and Hans Christian Andersen's tale "The Little Match Girl" "reveals the repetition of terrible events" (Volkova, 2012, 43). It sets a paradoxical life cycle, interrupted with a gospel quote - "Let the children come to me and do not forbid them not, for the Kingdom of Heaven belongs to such as these". The sounding phrase breaks "the quiet", finishing an important conceptual triad "pause" - "silence" "quiet" and creating a new ethical optics that destroys the polarities (graphical visualization of the words "white", "black", "snow", "summer", "bread", "rye", "roundabout", "ice cream", "she", "mother").

In other words, the sentimentalist discourse of Levanov's text is associated with the performative activity of the latter. At that familiarizing the reader with the category of sensitivity, that is traditional for sentimentalism, is problematized, the expression of the category being the reader's image explication manifested in periodic references to it (e.g., "Poor Liza" by N.M. Karamzin).

As for V. Levanov's play, mediated actualization of the same mechanism becomes an evidence of destruction and inner negativism of the category of sensitivity. Indirect projection of sentimentalist discourse on the reader's implicit image turns into a statement of the reader's involvement in the death of the "children's" world, acquiring not the feature of randomness (marginalized parents' position) but that of regularity. According to T.N. Volkova, "the cause of the two boys' terrible death is none other than the reader himself" (Ibid., 43).

Thus, sentimentalist discourse in its complex relations with various versions of postpostmodern artistic paradigm performs primarily an axiologizing / de-axiologizing role. Thus, the problem of interrelationship of sentimentalist discourse and traditionalist artistic paradigm, which formally does not need an additional axiological regulator, is of a particular interest. Revealing the dynamics of the sentimentalist discourse functioning in the Russian literature of the second half of the XX century, the researchers from time to time refer to V. Astafiev's novel "Shepherd and Shepherdess", the idyllic allusions of which can serve a formal criterion to include this work into the neosentimentalism trend. However, conceptually V. Astafiev's novel completely misses its sentimental code. According to N.V. Kovtun's reasonable opinion, an idyllic plane becomes only a form of the utopian discourse presentation that is possible due to a Christian code which is more traditional for the writer.

In our opinion, V. Gurkin's dramaturgy and, rather, some of his texts can serve a more adequate illustration of the problem of traditionalism and sentimentalist discourse interaction. With this regard two plays - "Love and Pigeons" and "Baltic Quadrille" - are of a particular significance. In general, the sentimentalist discourse in the playwright's works manifests itself quite consistently. However, in most plays it is represented implicitly, mainly at the level of the author's intention declared by the title of the play, "The Musicians, or the Legend of the Righteous Carrier", "Lighting a Candle at Day Time... / Andrew. His Story in Three Parts". In the latter case the presence of sentimentalist discourse is emphasizes with both a reminiscential character of the first part of the title (E. Bachurin "I want to love") and a 
language form of the second part ("Andrew. His Story in Three Parts").

In contrast to this, sentimentalist discourse actively manifests itself at the structural level of the plays "Love and pigeons" and "Baltic Quadrille". The obvious element of the structural diversity of the plays is an active use of an anecdotal intrigue realized within the framework of the vaudeville tradition. It is particularly clear in "Baltic Quadrille", its title transforming an anecdotal intrigue in a vaudeville form by making one of the primary genre markers of vaudeville. Regardless of the fact that "Love and Pigeons" does not openly declare the presence of this attributive feature, its potential presence is still felt. A deliberate discontinuity of the structure, which is manifested in self-sufficiency of external eventfulness of each scene, has become the basis of the inclusion of the same quadrille component in the film adaptation of the play.

Vaudeville tradition in these texts turns out to be a form of resuscitation of sentimentalist discourse, which is not identical but provoked by it. Vaudeville, that is typical for post-Vampilov theatre, produces activization of the category of case. It is known that in A. Vampilov's dramaturgy the case "paradoxically organizes the world, gives it a sense of value, facilitates the resolution of conflicts... The case is a live life; it confronts an "external order" (Kudimov), social and everyday repeatability, stereotypic thinking" (Sobennikov, 2012, 26-27).

Similar functioning of the category of case is also typical for V. Gurkin's plays. In his "Baltic Quadrille" and "Love and Pigeons" a case reveals its value meaning of a routine everyday existence, the category of sensitivity being the embodiment of this value meaning. This situation is complicated with the variability of presented themes, traditionally reconstructing this category, these themes being family, children, etc. Almost all the dialogues in both plays focus on them. As for historical background, appearing very fragmentarily and associated mainly with a catastrophic or dramatic effect of macro-history, it should emphasize the importance of family values as the basis of micro-historical nucleus.

However, this does not happen. With the declared polarization of micro- and macrohistory the theme of alcohol and that of money, related to it, become the main content of a family line. The characters regard the former as the main factor of disharmony, and the latter - as a material equivalent of successful family life. Thus, there arises a situation similar to that in V. Krupin's story "Live water", for example. The theme of alcohol becomes a formal reason of disharmony of rural life, but its destruction is of a directly opposite effect. The theme of alcohol in V. Gurkin's texts creates the effect of predictability of life, losing its inner complexity and depth and turning into a constantly repeatable ritual.

Repeatability and replication of the ritual of life is ensured through the technique of doubling the pairs with its reference to the same quadrille component. Such pairs as Mitya Sanya / Nadya - Vasya ("Love and Pigeons"), and Nikolai Zvyagintsev - Lida / Sasha Aref'ev Valya ("Baltic Quadrille") are subject to the logic of quadrille and swap freely. This case is not so much about their inner similarity which is due to the inclusion of characters in a single world in the traditionalist literature. It is much more about the idea of leveling and standardization of life characteristic of the literary context of the 1970s.

Loss of stereoscopicality of life is also revealed by outplaying of one of the principles of image creation, when the speech element becomes a leading and almost the only element of image structuring, in contrast to village prose, for example. It does not embody a character's distinctive identity but becomes the basis for stereotyping and standardization of 
the characters' images. Having lost its organic nature, folk speech element turns into one of the open comicality forms. It becomes a system of clichés and functionally identifies itself with a bureaucratic or distorted version of the intellectual language discourse.

Identification of the second version of the category of sensitivity that is directly related to the sentimentalist discourse in the play settles the disharmony demonstrated. Its activation is due to the inclusion of a case and helps to overcome a cliché character of life by not so much revealing its spiritual content but by fully restoring the category of corporeity. The emphasis on the latter is associated primarily with the author's desire to reconstruct the life circle model significant for the traditionalists, the life circle presenting not only the infinity of the world's vital nature but also defining the integrity of the character's existence. In this sense V. Gurkin's dramaturgy can be an example of some kind of a creative dialogue with the already established schemes of the traditionalist literature. All traditional means of its embodiment are considered in the plays through the prism of "the minus technique". As for resuscitation of lost meanings, it is possible through sentimentalist discourse involvement, the discourse being not one of the most frequent elements of the traditionalist poetics.

Thus, the tendency of neosentimentalism is consistently represented in the Russian literature of the last third of the XX - beginning of the $\mathrm{XXI}$ centuries. It is primarily associated with the restoration of rights of the category of corporeality which, in its turn, can be a means of building a new ethical optics either directly designing it or setting it off. In the case of integration with traditionalism, sentimentalist discourse is much more functional as it nearly loses the role of value regulator becoming a mechanism of reconstructing the essential foundations of life which are forgotten but not vanished.

\section{References}

Deleuze, G., Guattari, F. (2007). Anti-Oedipus. Capitalism and schizophrenia. Ekaterinburg, $672 \mathrm{p}$.

Dubrovina, I.V. (2013). Funktsionirovanie sentimentalistskikh kodov v poetike sovremennoi dramy (na material dramaturgii Nikolaia Koliady): dis. ... kand. filol. nauk [Functioning of the sentimental codes in the poetics of modern drama (in the drama of Nikolai Kolyada): Dissertation of Candidate of Philology]. Stavropol, $261 \mathrm{p}$.

Dugin, A. Novaia Drama kak iavlenie Postmoderna [New drama as Postmodernism phenomenon]. Centre for conservative studies. Available at: http://konservatizm.org/konservatizm/ sociology/280610193723.xhtml (accessed 15 August 2016).

Foucault, M. (1996). Nitshe, genealogiia i istoriia [Nietzsche, genealogy and history]. Filosofiia epokhi postmoderna: sbornik perevodov i referatov [Philosophy in the postmodernism era: collection of translations and essays]. Minsk, 74-97. Digital library on philosophy. Available at: http://filosof. historic.ru/books/item/f00/s00/z0000552/ (accessed 15 August 2016).

Leiderman, N.L., Lipovetskii, M.N. (2001). Sovremennaia russkaia literature: $v 3 \mathrm{kn}$. Kn. 3: V kontse veka (1986 - 1900 gody) [Modern Russian literature: in 3 vol. Vol. 3: At the end of the century (1986-1900-ies)]. Moscow, $160 \mathrm{p}$.

Prokhorova, T.G. (2012). K voprosu o neosentimentalizme v sovremennoi russkoi proze (na materiale tvorchestva L. Ulitskoi i L. Petrushevskoi) [On neosentimentalism in modern Russian prose (based on L. Ulitskaia's and L. Petrushevskaia's works)]. Dergachevskie chteniia - 2011. Russkaia 
literature: natsional'noe razvitie i regional'nye osobennosti: materialy X Vserossiiskoi nauch. konf. T. 2 [Dergachev readings - 2011. The Russian literature: national development and regional peculiarities: proc. of X All-Russian scientific conference. Vol. 2]. Ekaterinburg, 416 p.

Sobennikov, A.S. (2012). Sud'ba i sluchai v dramaturgii A. Vampilova [Fate and chance in A. Vampilov's drama], In Vestnik Novosibirskogo gosudarstvennogo teatral'nogo instituta [Novosibirsk State Theatre Institute]. 4, $138 \mathrm{p}$.

Volkova, T.N. (2012). Zvuk i tishina v p'ese Vadima Levanova "Vygliadki" [Sound and silence in Vadim Levanov's play "Peeping Outs"], In Novyi filologicheskii vestnik [New Philological Bulletin]. $2(21), 43$.

\section{Традиционализм через призму \\ неосентименталистского дискурса \\ (на примере драматургии В. Гуркина)}

Т.Н. Бреева

Казанский (Приволжский) федеральный университет Россия, 420008, Казань, ул. Кремлевская, 18

В статье рассматривается специифика функиионирования тенденции традиционализма в русской литературе второй половины XX века в контексте неосентименталистского дискурса. Универсальность и функииональная множественность последнего обеспечивает его широкое проникновение в литературный процесс этого времени и сопряжение с самыми разнылм литературными феноменами: постмодернизмом, женской прозой, литературой «нового биографизма», «новой драмой» и т.д. Активизация неосентименталистского дискурса, становящаяся способом преодоления кризисных результатов постмодернистской интеллектуальной парадигмы, выполняет в основном функциюю реабилитации, реанимируя совокупность констант, в том числе и этических, человеческого существования. Аксиологизирующий потенцииал неосентименталистского дискурса реализуется посредством категории телесности, приобретающей позитивные смысловые коннотации. Взаимодействие неосентименталистского дискурса с литературой традиционализма свидетельствует о кризисном состоянии последней и стремлении разнообразить формы и способы художественного выражения.

Ключевые слова: литература русского традиционализма, неосентименталистский дискурс, постмодернистская художественная парадигма, женская проза, драматургия В. Гуркина.

Научная специальность: 10.00.00 - филологические науки. 